\title{
Crossing the bridge: foreign language students' reciprocal images in (inter)cultural mediation between Portugal and Turkey
}

\section{Daniel Basílio, Maria Helena Araújo e Sá \& Ana Raquel Simões}

To cite this article: Daniel Basílio, Maria Helena Araújo e Sá \& Ana Raquel Simões (2016) Crossing the bridge: foreign language students' reciprocal images in (inter)cultural mediation between Portugal and Turkey, Language and Intercultural Communication, 16:1, 22-43, DOI: 10.1080/14708477.2015.1114209

To link to this article: http://dx.doi.org/10.1080/14708477.2015.1114209

Published online: 01 Feb 2016.

Submit your article to this journal $\sqsubset$

Џلll Article views: 132

View related articles 5

View Crossmark data ¿ 


\title{
Crossing the bridge: foreign language students' reciprocal images in (inter)cultural mediation between Portugal and Turkey
}

\author{
Daniel Basílio, Maria Helena Araújo e Sá and Ana Raquel Simões \\ Department of Education, Research Centre Didactics and Technology in Teacher Education (CIDTFF), \\ University of Aveiro, Aveiro, Portugal
}

\begin{abstract}
This study intends to highlight the role that Foreign Language Education (FLE), particularly in the Higher Education context, can play so as to contribute to the rapprochement of two distant and still mutually unknown countries such as Portugal and Turkey. In this sense, it ultimately aims at supporting the training of intercultural speakers, capable of promoting an effective Intercultural Dialogue between the two countries. A diagnosis is presented of the reciprocal images of Portuguese and Turkish students learning each other's language and culture. Conclusions are drawn on how their self- and hetero-images may pertain on the construction of their identities, on their awareness about and attitudes towards each other, on their motivation to learn each other's language, and on intercultural communication itself. Allying the study of Images of Languages and Cultures and the concept of Intercultural Competence in the study of students' representations within the FLE research tradition, a content analysis was carried out of the responses given to an inquiry by questionnaire. Conative implications of the students' images as revealed in the results were pointed out. Some important distinctions are highlighted in the reciprocal images of both groups. On this basis, recommendations for FLE are made focusing on the positive reconstruction of students' reciprocal images.
\end{abstract}

Este estudo pretende destacar o papel do Ensino de Línguas Estrangeiras (ELE), no contexto do Ensino Superior, na aproximação de dois países distantes e ainda mutuamente desconhecidos como são Portugal e a Turquia. Visa-se, em última instância, fomentar a formação de falantes interculturais capazes de promover um efetivo Diálogo Intercultural entre os dois países. É feito um diagnóstico das imagens recíprocas de dois grupos de estudantes portugueses e turcos a estudarem a língua e a cultura um do outro. São tiradas conclusões sobre as implicações das respetivas auto- e hetero-imagens na sua construção identitária, conscientização e atitudes relativamente ao Outro, na sua motivação para o estudo da língua da sua contraparte e na própria comunicação intercultural. Com base na conjugação do conceito de Imagens de Línguas e Culturas com o conceito de Competência Intercultural no estudo das representações dos

\section{KEYWORDS}

Foreign language education; intercultural awareness; intercultural competence; intercultural dialogue; images of languages and cultures 
alunos na tradição investigativa em ELE, realizou-se uma análise de conteúdo das respostas a um inquérito por questionário, sendo apontadas as implicações conativas das imagens recíprocas dos participantes tal como as revelam os resultados. Com base nas diferenças observadas nas imagens recíprocas de ambos os grupos, são feitas recomendações relativamente à ELE com enfoque na reconstrução positiva destas imagens.

\section{Introduction}

Political relations between Portugal and Turkey have been steadily growing in the last five years, as several important state visits and the signature of multiple bilateral agreements regarding a wide area of interests can attest. The main issues discussed in these bilateral encounters, ultimately aiming at furthering the rapprochement of the two nations, have been the strengthening of commercial relations, the promotion of Turkey's European Union (EU) membership (Portugal being a long-time full supporter), the promotion of a 'Mediterranean solidarity' (based on the shared European-Mediterranean identity which makes the geographic distance between the two countries extraneous), and the development of a so-called 'triangular cooperation' (Portugal and Turkey are seen as gateways to other markets such as the Portuguese ex-colonies and the former Ottoman empire possessions).

Political leaders of both countries have been emphasizing the 'special relation' that currently exists between their nations, highlighting the cultural bridges that connect them, and frequently mentioning Portugal and Turkey's shared identities, values and goals, as to ally economic diplomacy to a speech very closely related with the principles of Intercultural Dialogue. ${ }^{1}$ However, they also acknowledge that the relationship between the two countries is 'still far from reaching its true potential', being in a 'very embryonic state', recognizing that, at this moment, there is a compelling need to develop a deeper mutual knowledge, and foster the development of contacts and relations between them (e.g. Lusa, 2014).

In fact, economic relations between Portugal and Turkey are still rather weak as shown by the relatively low gross value of their commercial exchanges (in terms of exports, in 2012, Portugal was placed at the 51st position in the Turkish market and Turkey in the 48th in the Portuguese market). As for the mobility of people, recent data indicate that tourism exchanges are still incipient, and that only about 300 Turkish and Portuguese citizens are currently residing in Portugal and Turkey, respectively. As for Erasmus students' mobility, although the numbers have been slowly increasing, they are still very low. In 2011-2012, the year our data collection was carried out, Portugal received only $3.9 \%$ of the total number of Turkish students participating in the Erasmus programme, and Turkey received only $1.4 \%$ of the total of Portuguese Erasmus students (cf. European Commission, 2013).

With respect to Foreign Language Education (FLE) at the higher education level, neither country currently offers a degree either in the Portuguese or in the Turkish language. In the academic year of 2011-2012, FLE regarding both languages amounted only to 4-6 hours a week 'language courses' delivered in 5 universities in Portugal (out 
of a total of 52 universities), and in 3 universities in Turkey (out of a total of 165). As for the number of students learning each other's language at the higher education level in both countries, the numbers are also extremely low, as in the same academic year, there were only 30 Portuguese students (from a total of about 380,000, i.e. $0.08 \%$ ) learning Turkish in Portugal, and only 80 Turkish students (from a total of about 3,000,000, i.e. $0.03 \%$ ) learning Portuguese in Turkey. ${ }^{2}$ Recent data indicate that this panorama has not improved much lately.

The present study focuses on the importance of strengthening intercultural awareness and dialogue between Portugal and Turkey. FLE has a fundamental role to play in this field, as current research shows that promoting language teaching based on an intercultural approach can support and further develop a general mutual interest and awareness, as well as stronger and deeper ties (economic, political, cultural, and also affective) between peoples and countries (e.g. Byram, 2008; Guilherme, 2002; Zarate, GohardRadenkovic, Lussier, \& Penz, 2004).

Knowing that the representations that individuals construct of themselves and others are one of the fundamental factors in intercultural communication (e.g. Byram, 1997, 2008, 2009), we based the conceptual framework of our study on the dialogical relation between FLE, Intercultural Competence (IC), and Images of Language and Cultures, and focused on the reciprocal images of Portuguese and Turkish university students and their role on the development of Intercultural Dialogue and mediation between the two nations, cultures and peoples.

In this context, we analyse some of the responses to an inquiry by questionnaire for Portuguese and Turkish students related to the images they construct of their own people, country, and culture, and their counterpart's. Based on this diagnosis, we draw conclusions on how these images can influence the two groups' knowledge of, and attitudes towards each other, offering some general guidelines regarding IC development in the context of FLE in both languages.

\section{Images in FLE and intercultural communication}

In today's globalized world, it is strongly ascertained that FLE's main goal has to be that of enabling learners to effectively interact with people with a different language and cultural heritage, that is, to develop the necessary competencies to support successful intercultural interaction. Recent theory (cf. Deardorff, 2009) combines these competences into a single composite and multidimensional concept referred to as IC, defined as a complex of competencies necessary to function appropriately and effectively when interacting with people who are linguistically and culturally different from oneself, involving not only the proper management of such interactions, but also the openness to step beyond one's own culture and recognize different or divergent affective, cognitive, and behavioural orientations to the world (cf. Fantini \& Tirmizi, 2006; Sinicrope, Norris, \& Watanabe, 2007; Spitzberg \& Chagnon, 2009). In this perspective, IC is the necessary condition for the development of Intercultural Dialogue as defined by the Council of Europe (2008), that is, an open and respectful exchange of views between individuals and groups with different backgrounds, based on mutual understanding, and requiring the willingness and capacity to listen to the views of others. 
In order to fulfil this ambitious goal, it is necessary to adopt an intercultural paradigm (Abbdallah-Pretceille, 1999) in the context of FLE based on a simultaneously communicative and critical approach (Guilherme, 2002) that enables the learners to become true 'intercultural speakers', that is, individuals who develop

the skills of a mediator, someone who can understand different cultural perspectives and the relationships among them AND who develops a 'critical cultural awareness' i.e. an ability to critique their own and other people's values and beliefs from a consciously developed philosophical perspective. (Byram, 2007, p. 15)

This (inter)cultural mediation is seen by Zarate et al. (2004) as 'an expertise of the relationship with the Other which [ ... ] enhances the social assets of "multiple belonging"' (p. 11) by involving a 'set of attitudes, strategies and practical skills geared to countering prejudices, stereotypes and xenophobic representations' (p. 17), thus contributing to the crossing of the intercultural bridges that link cultures and individuals.

Social and cultural identities, therefore, interplay in intercultural communication as they are a reflection of the individual's multiple affiliations within a sociocultural system (sex, age, social class, nationality, religion, etc.), being responsible for the distinction between groups, which are mostly grounded on cultural differences (cf. Cuche, 1999). Identification being, at the same time, differentiation, distinctions depend mostly on the will to create a frontier between 'us' and 'them', instituted by a kind of compromise and negotiation between the individuals and groups on how they want to be characterized, and on the characteristics the others attribute to them (Barth, 1995). Social borders have, therefore, an eminently symbolic nature, as what really separates the different groups is not cultural difference in itself, but their will to differentiate themselves.

As intercultural communication inevitably envelops negotiating cultural identities and associated self- and hetero-images, there is a need to address, in FLE, the learners' expectations regarding the Other, who appears different when seen as a member of a larger community, sharing a common set of beliefs, values, and social practices, in other words, a common culture (cf. Lustig \& Kroeger, 2010). Both knowledge and attitudinal factors, which are closely related to the images that the individuals construct of the world, of themselves, and of the Other, are thus established as preconditions for effective intercultural interaction.

Intercultural reflection upon otherness must be fostered, fundamentally based on the development of the learners' abilities to unfold the similarities between themselves and the Other, and establish a common ground where both effective and expected differences are problematized (cf. Abdallah-Pretceille, 1999). Recent research, both in Portugal and in Turkey, has highlighted the importance and productivity of cultural awareness in FLE (e.g. Araújo e Sá, De Carlo, \& Melo-Pfeifer, 2010; Araújo e Sá \& Pinto, 2006; Bayyurt, 2006; Genç \& Bada, 2005; Razı, 2012; Zehir Topkaya \& Demir, 2011). These studies show that cultural awareness activities in FLE have to be grounded on the principle that 'people should be regarded as complex human beings' having 'multiple identities', involving 'the interaction of one's own individuality with others' identities', as only 'after familiarizing themselves with their native culture's values' will learners be able to 'better realize the differences in the target culture' (Raz1, 2012, p. 170). For Byram (1997, 2009), the intercultural speaker improves his/her level of awareness regarding both his/her own culture, and the culture of the Other, by a simultaneous effort of interpretation of these two 
realities, which implies the development of five distinct and interconnected factors or savoirs that constitute his multidimensional model of IC (cf. Byram, 2009, p.323) (see Figure 1).

According to this model, intercultural speakers must develop, through 'critical cultural awareness', a personal understanding of how their social identities were acquired, and of how they function as a prism through which both the members of their intragroup and those of the intergroup are seen. This requires that they mature their pre-existent knowledge, and adopt attitudes of curiosity and openness to diversity, by using their skills of discovery and interaction, as well as of interpreting and relating. It is the combination of these savoirs that might allow them to manage the possible dysfunctions involved in intercultural contacts.

In this sense, we can understand how Byram's multidimensional model of IC, which is largely centred on the identity negotiation processes that occur within the context of cultures (Spitzberg \& Chagnon, 2009, p. 17), is interconnected with the study of images as it is assumed that language learning, by implying the learning and understanding of the specificities (linguistic, social, and cultural) of any given social or cultural being, must focus on the continuous (re)elaboration of the learners self- and hetero-representations.

Language education research proposes a concept of image as a system of interpretation of reality anchored in historical, socio-identitary, cognitive and discursive processes, specific to each subject or group, and partaking in their process of grasping and

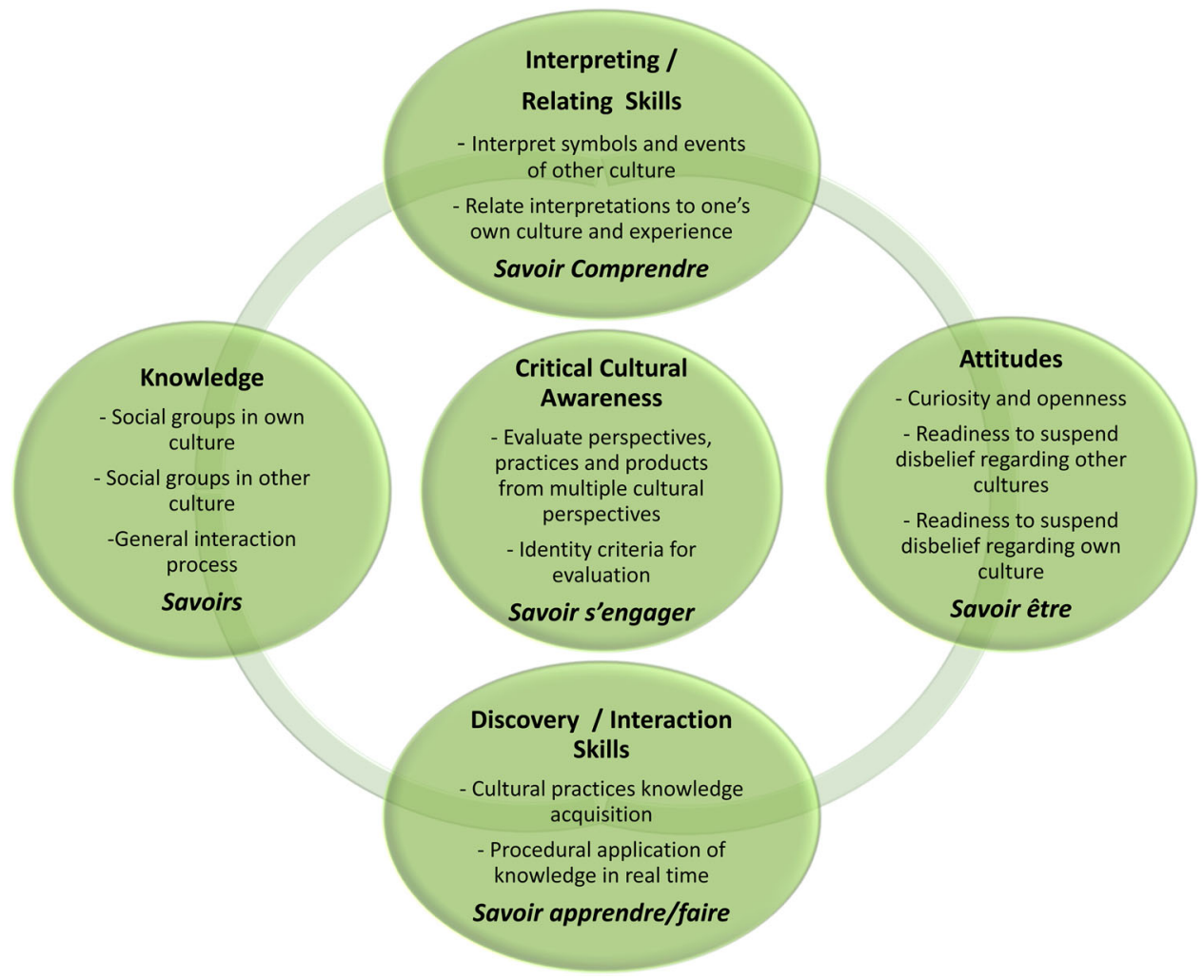

Figure 1. Byram's Multidimensional Model of IC (reproduced and adapted with author's permission). 
constructing reality, influencing the ways in which the subject or group interacts with it (cf. Araújo e Sá \& Pinto, 2006). Images are, thus, strongly connected with identity construction as, by functioning as a basis for interpersonal and intergroup exchanges, as cognitive and semiotic tools, and as markers of identity (cf. De Pietro \& Müller, 1997), having a pragmatic functionality that influences the perception, the actions, and the relations of individuals, groups, or societies (cf. Abric, 1994; Coste, 2001; Jodelet, 1997), they constitute the basis for the description of the self and the Other.

As social constructs, images are the product of inherently dynamic and evolving processes, being constantly (re)created by the individuals and groups according to their own history and experiences, influencing their relations, as their reciprocal images, knowingly or unknowingly, continuously interplay in discourse (cf. Porcher, 1997). They are therefore liable to be constantly developed and further elaborated, for instance, by the pressure of attitudes as social practices, or by the transformation of their intrinsic content (cf. Mannoni, 1998).

It is in this sense that image studies aim at intervening in the worldviews and value systems of the individuals by developing processes of image deconstruction and reconstruction fundamentally based on an understanding and acceptance of the Other's identities and points of view. This does not necessarily imply agreement, rather openness and acceptance of ambiguity and uncertainty, based on a perspective in which the others are seen as equals in their differences (cf. Abdallah-Pretceille, 1999). By implying a reflective and analytical effort involving problematizing both the speaker's own culture and the Other's (i.e. the development of a 'critical cultural awareness'), image reconstruction acquires the utmost importance in fostering an open and deeper interaction between people with different languages and cultures, and, ultimately, Intercultural Dialogue.

Hence, the study of images gains great importance in FLE as the diagnosis of the images that circulate in a specific context promotes the understanding of their influence on the construction and maintenance of social and cultural identities - which necessarily interplay in communication (cf. Byram, 1997) - on the motivations for choosing to learn a particular foreign language and interact with individuals who speak that language (cf. Rouault, 2001; Walt, 2004), on the development of language and cultural awareness (Mariko, 2005), and, finally, on the processes involved in language and culture education and learning (cf. Castellotti \& Moore, 2002), especially in what concerns the development of the learners' IC.

\section{Methodological design}

This study is part of a wider research project entitled Reciprocal images of Turkish and Portuguese University students: for an (inter)cultural mediation between Portugal and Turkey. This project aims at (i) diagnosing the Portuguese and Turkish students' reciprocal images of languages and cultures in the context of FLE at the higher education level in both countries, and (ii) understanding their possible implications for the reciprocal awareness and intercultural communication between both peoples, as well as for the promotion and development of Portuguese and Turkish languages and cultures in both countries. On this basis, we devised the following procedures: 
(1) Diagnose reciprocal images of Portuguese and Turkish University students.

(2) Analyse how these images are related.

(3) Assess the influence they might exercise:

(3.1) on the relationship of the subject with his/her own language and culture and the Other's and on the structuring of his/her identity;

(3.2) on foreign language and culture teaching-learning;

(3.3) on intercultural communication.

(4) Provide FLE guidelines based on the principles of an intercultural approach to FLE aiming at enabling learners to become effective intercultural mediators between Portugal and Turkey.

We adopted a Multiple Cases variant of a Case Study project (Yin, 2009) as to allow us, by means of a 'comprehensive research strategy', to compare the results of the two groups, and infer how they can be interrelated. Although several data collection tools were used in the wider project, in this study, we confine ourselves only to some of the data collected by means of an inquiry by questionnaire.

In terms of data processing and interpretation, we developed a content analysis methodology based on an eminently qualitative approach (not dispensing with, however, the use of statistical instruments). Within the tradition of the study of images, and always bearing in mind that they have a dynamic and changeable nature, and are thus liable to be continuously deconstructed and reconstructed, we adopted a 'thematized' approach in which images are taken as elements liable to explain attitudes, competences and behaviours inherent to an individual or group, and as possible pathways for the understanding of the individual's world organization system (cf. Vasseur, 2001).

The results obtained are not intended to be generalized, as they aim only at achieving a deeper level of understanding of the students' reciprocal images and of their implications for FLE, intercultural awareness and also intercultural communication.

\section{Data collection and materials}

In November 2011 (first semester), we applied an online questionnaire - 'Images Questionnaire' - to Portuguese and Turkish higher education students who were attending, in their own countries, the first and the second years of Turkish and Portuguese foreign language courses, corresponding respectively to levels A and B of the Common European Framework of Reference for Languages (Council of Europe, 2001). Two versions of the Questionnaire were devised, one in Portuguese for the Portuguese students, and one in English for the Turkish students (as we were assured they were proficient in this language). In both cases, the respondents were instructed to answer in their own native languages. For the purpose of the data analysis presented in this paper, all the respondents' answers were subsequently translated into English. The 'Images Questionnaire' was structured in five main sections each one comprising specific research objectives (see Table 1).

In this paper, we will focus on the results of a set of word-association exercises related to the images of the Portuguese and Turkish peoples (section 4), and of a multiple-choice question regarding the values that the respondents dominantly associate with their own and their counterpart's country as well as to the EU (section 5). 
Table 1. 'Images Questionnaire' structure and objectives.

\begin{tabular}{|c|c|}
\hline Sections & Objectives \\
\hline 1. Sociocultural personal data & Characterize the learners in terms of elements of fact. \\
\hline 2. Linguistic biography & Describe the learners' linguistic biography. \\
\hline $\begin{array}{l}\text { 3. Images of the Turkish and Portuguese } \\
\text { languages }\end{array}$ & $\begin{array}{l}\text { Describe the self-/hetero-images of the learners regarding Turkish and } \\
\text { Portuguese languages. }\end{array}$ \\
\hline $\begin{array}{l}\text { 4. Images of the Turkish and Portuguese } \\
\text { peoples and cultures }\end{array}$ & $\begin{array}{l}\text { Describe the self-/hetero-images and attitudes of the learners regarding } \\
\text { Turkish and Portuguese peoples and cultures. }\end{array}$ \\
\hline 5. Opinions and attitudes regarding EU & Describe the images and attitudes of the learners regarding the EU. \\
\hline
\end{tabular}

\section{Participants}

As pointed out in the 'Introduction' section, the number of Portuguese and Turkish students learning each other's language and culture in the context of the Higher Education system of their respective countries is extremely low. In the 2011-2012 academic year, only three universities in Turkey offered Portuguese language courses, and, in Portugal, only five universities offered Turkish language courses. The number of students attending these courses amounted to only 80 students in the Turkish context and 30 students in the Portuguese context. It is also worth mentioning that, in all cases, the FLE teachers were native speakers, and that none of the researchers was involved in teaching in either context.

It was within this general setting that the 'Images Questionnaire' was presented, in Portugal, to 24 students attending both Lisbon University and Oporto University (this number corresponding to $80 \%$ of the total number of students learning Turkish in Portugal). In Turkey, the Questionnaire was presented to 67 students attending Ankara University (corresponding to $84 \%$ of the total number of students learning Portuguese in Turkey). We obtained 17 valid answers in Portugal and 41 in Turkey. Even though we recognize that it is a rather limited number of responses, they actually correspond proportionately to $51 \%$ of all students learning Portuguese and $57 \%$ of all students learning Turkish.

Indeed, the scarcity of students learning each other's language, in Portugal and in Turkey - which was already noticed by one of this study's proponents while working, back in 2009, as cultural adviser for the Portuguese Embassy in Turkey (Ankara) and as Portuguese language lecturer at two Turkish Universities (Ankara and Izmir) - was one of the main factors that prompted our research project, as we wished to shed some light on the factors that might be involved in such a low rate of enrolments in these courses, and ultimately to contribute to its improvement.

In terms of the characterization of participants in each group, although both groups share some similarities, they also present relevant differences (see Table 2).

When compared with the Turkish group, the Portuguese group is more heterogeneous, including students who are not formally developing their studies in the higher education context and students who are developing their language studies in the 'open course' format. It is also more diversified in terms of the students' age and academic background.

Respecting direct contact and relationship with their counterpart, some important differences can be observed between the two groups. Regarding the Portuguese group, $47 \%$ have already visited Turkey (47\% tourism; $12 \%$ relationship; and/or $18 \%$ European Mobility Programmes) and $47 \%$ maintain a relationship with a Turkish native speaker (41\% friendship; $6 \%$ romantic; $6 \%$ acquaintance; and/or $6 \%$ professional/academic). 
Table 2. Characterization of the respondents.

\begin{tabular}{lll}
\hline Case & \multicolumn{1}{c}{ Portuguese Group $(n=17)$} & \multicolumn{1}{c}{ Turkish Group $(n=41)$} \\
\hline Sex & 82\% female & $78 \%$ female \\
Age & 19 to over $45(71 \%<26)$ & $22-27(90 \%<26)$ \\
FLE modality & $53 \%$ 'open course' & $63 \%$ mandatory discipline \\
& $47 \%$ optional discipline & $37 \%$ optional discipline \\
Academics & 65\% Higher Education students & $100 \%$ Higher Education students \\
Study area & 71\% Humanities; 17\% Sciences; 12\% Law & 100\% Humanities \\
Foreign languages & 5-6 FL learnt/in learning & 3-4 FL learnt/in learning \\
\hline
\end{tabular}

Regarding the Turkish group, only one student (2\%) has visited Portugal and, though 34\% declare that they maintain a relationship with a Portuguese native speaker $(17 \%$ friendship; $15 \%$ student-teacher; and/or $10 \%$ professional/academic), more than a half mean exclusively their teacher. We must mention that it is easier for the Portuguese, as EU citizens, to travel to Turkey than it is for the Turkish to travel to Portugal. Turkish citizens need to go through the bureaucratic process of acquiring a Schengen visa to visit other European countries, which may constitute a deterrent factor when considering a visit to Portugal.

The Portuguese group also presents a more positive self-assessment of their knowledge about their counterpart's country and culture when compared to the Turkish group, as we can see in Figure 2.

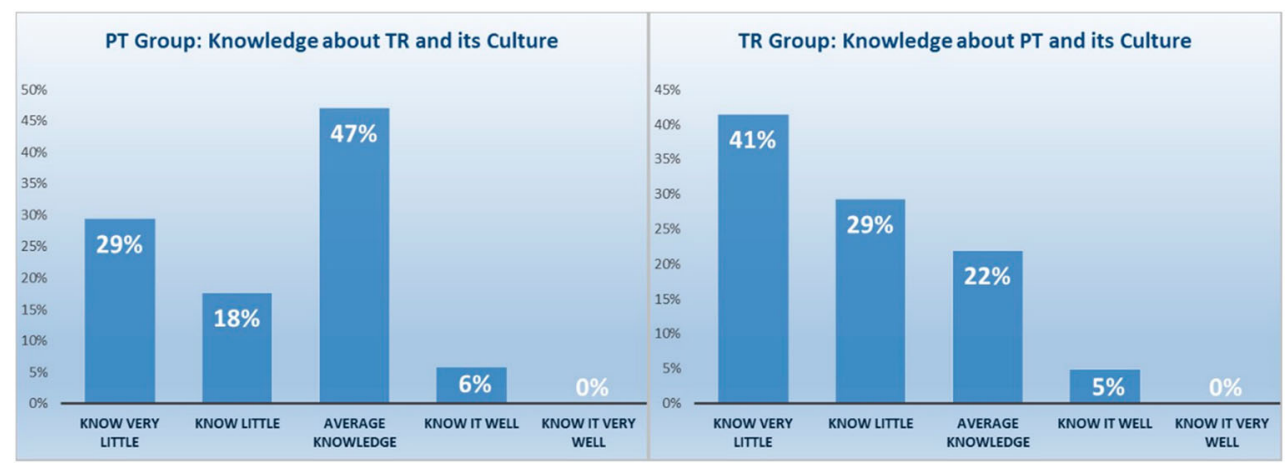

Figure 2. Knowledge about counterpart's country and culture (self-assessment).

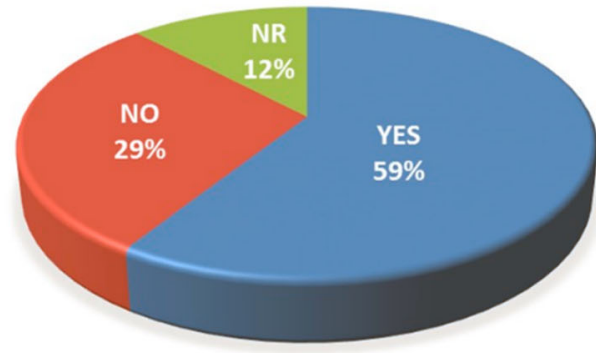

PORTUGUESE GROUP

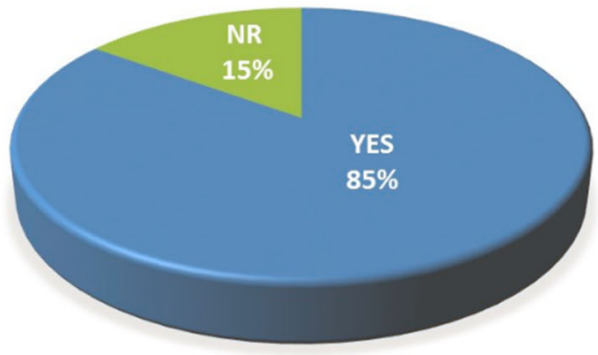

TURKISH GROUP

Figure 3. Importance of learning counterpart's language. 
Table 3. Main motivations to learn the counterpart's language.

\begin{tabular}{ll}
\hline Ranking & \multicolumn{1}{c}{ Main reasons to learn counterpart's language } \\
\hline $\begin{array}{l}\text { Portuguese Group } \\
\text { 1st (53\%) }\end{array}$ & To get to know the TR culture better. \\
2nd (35\%) & To get a job or a professional promotion. \\
3rd (29\%) & $\begin{array}{l}\text { To communicate with friends, family and/or boy/girlfriend. } \\
\text { Because knowing TR facilitates communication with speakers of same linguistic family. } \\
\text { It is important for my future to know more languages. } \\
\text { To improve one's general culture. }\end{array}$ \\
& To open up possibilities of working in Turkey or TR speaking country. \\
Turkish Group & It is important for my future to know more languages. \\
1st $(49 \%)$ & To get a job or a professional promotion. \\
2nd (41\%) & To increase business opportunities. \\
3rd (41\%) & To open up possibilities of working in Portugal or PT speaking country. \\
4th (32\%) &
\end{tabular}

However, regarding the importance conferred to the learning of the counterpart's language, the Turkish group is more assertive in their valorization of learning their counterpart's language than the Portuguese group (see Figure 3).

In terms of motivations for language learning (cf. Dörnyei, 2003; Masgoret \& Gardner, 2003), the Turkish group shows a clear tendency to present mainly pragmatic and instrumental reasons to learn Portuguese, whereas the Portuguese group shows a tendency to present mainly integrative and affective reasons to learn Turkish (see Table 3).

These results are concomitant with the fact that foreign language acquisition (especially when it comes to English, but also, to other European languages like German, French, Spanish, etc.) has been, as Alptekin and Tatar (2011, p. 330) point out, historically regarded in Turkey as strongly related to professional and economic advancement within both the public and the private sectors.

\section{Analysis of the results}

\section{Reciprocal images of peoples: word-association exercises}

As one of the techniques to assess the reciprocal images of the students, we asked them to answer the set of four word-association questions presented in Table 4.

Associograms 2 and 3 refer to the self-images that the respondents construct regarding themselves as a people. Associograms 1 and 4 refer to the hetero-images that the respondents construct about their counterpart's people. While questions 1 and 2 aim at collecting the respondents' 'direct' self- and hetero-images, questions 3 and 4 intend to collect the self- and hetero-images as intermediated by the respondents' perception of how their people see and are seen by their counterpart. The latter questions, regarded as 'indirect' self- and hetero-images, have a broader social nature, rather than a strictly personal one.

Table 4. Reciprocal images word-association questions.

\begin{tabular}{|c|c|}
\hline Portuguese public version & Turkish public version \\
\hline \multicolumn{2}{|c|}{$\begin{array}{ll}3 \text { words or expressions that come to your mind to ... } & \\
\text { 1a. describe the Turkish people } & \mathbf{1 b} \text {. describe the Portuguese people } \\
\text { 2a. describe the Portuguese people } & \mathbf{2 b} \text {. describe the Turkish people }\end{array}$} \\
\hline \multicolumn{2}{|c|}{3 words or expressions that come to your mind when asked to complete the sentence ... } \\
\hline $\begin{array}{l}\text { 3a. For the Turkish, the Portuguese people are ... } \\
\text { 4a. For the Portuguese, the Turkish people are ... }\end{array}$ & $\begin{array}{l}\text { 3b. For the Portuguese, the Turkish people are. } \\
\text { 4b. For the Turkish, the Portuguese people are. }\end{array}$ \\
\hline
\end{tabular}


To process the collected lexical items, which took the form of either adjectives or reduced relative clauses, we followed a content analysis approach which derived from an images categorization model used in FLE research in the University of Aveiro (cf. Araújo e Sá \& Pinto, 2006). Strongly drawing from the categorization model of stereotypes developed under a cognitivist approach (cf. Wojciszke, 2005), this model proposes five distinct categories of images of peoples and cultures: (1) psychological and moral traits; (2) competence-related traits; (3) socio-economic characteristics; (4) visual impact; and (5) linguistic-communicative profiles. Feeling the need to adapt this taxonomy to the results of a preliminary analysis of our data, we proceeded with the following redefinitions:

- In order to further elaborate the two first categories, we borrowed the taxonomy of the Five-Factor-Model (FFM) of personality traits (McCrae \& Costa, 1997, 2006). As our aim is to access the kind of personality traits the respondents ascribe to themselves and to the Other, and certainly not to describe their personality, we invoke solely the descriptive nature of the FFM and its five orthogonal factors of human personality: Extraversion (active, assertive, enthusiastic, outgoing, talkative), Agreeableness (appreciative, forgiving, generous, kind, sympathetic, trusting), Emotional Instability (anxious, self-pitying, tense, touchy, unstable, worrying), Openness and Intellect (curious, imaginative, insightful), and Conscientiousness (efficient, organized, responsible). We related the Extraversion, Agreeableness, and Emotional Instability factors to the Psychological and Moral traits category, and the Openness and Intellect, and Conscientiousness factors to the Competences category.

- We added the category 'Religion and Traditionalism' as a means of focusing on the expected relevance of these aspects in the shared images of the respondents.

- As we were confronted with a series of items specifically related to the ways the respondents position themselves in relation to the Other in what concerns a sense of proximity or distancing, and/or similarity or difference, we added the category 'Sense of Proximity or Distancing'. As all occurrences of lexical items referred to physical appearance were of a general character, being related either to 'attractiveness' (e.g. attractive, beautiful) or physical similarity, they were included in the subcategory 'Proximity'.

- We broadened the socio-economic characteristics category, renaming it as 'Sociocultural Elements', including not only social, economic, and political aspects, but also miscellaneous cultural-related elements.

In Table 5, we can see the final five image categories along with the most representative hyponyms contemplated in each category.

In Figures 4 and 5, we present the results of our categorization concerning both groups' responses to the word-association exercises.

When analysing Figures 4 and 5, the 'No Responses' (including 'no opinion' answers and blank spaces) must be taken into account. Agreeing with Pardal and Correia (1995, p. 58), we recognize that they can be quite meaningful. Indeed, there is an absence of such occurrences in associogram 2 (direct self-images), and a similarity of occurrences regarding all the remaining associograms. These results seem to indicate that the 'No Responses' are connected less with peripheral reasons (lack of attention or time to answer, misunderstanding of the questions), and more with a sense of distancing 
Table 5. Image categorization framework.

\begin{tabular}{|c|c|c|}
\hline Categories & Pole & Collected lexical items hyponyms \\
\hline \multicolumn{3}{|l|}{ 1. Psychological/Moral traits } \\
\hline \multirow[t]{2}{*}{ 1.1. Extraversion } & + & Lively; warm-blooded; sociable; outgoing; talkative; entertaining \\
\hline & - & Reserved; moderate; quiet \\
\hline \multirow[t]{2}{*}{ 1.2. Agreeableness } & + & Hospitable; good; trustworthy; loving; generous; friendly; nice; polite; helpful \\
\hline & - & Bad; distrustful; crude; unkind; disrespectful; rude \\
\hline \multirow[t]{2}{*}{ 1.3. Emotional stability } & + & Calm, patient; easy-going, relaxed; positive; joyful, happy \\
\hline & - & Nervous; impatient; angry; aggressive; bad-tempered; fatalistic; depressed \\
\hline \multirow[t]{2}{*}{ 2. Competences } & + & Open-minded; curious; intelligent; talented; educated; hardworking \\
\hline & - & Close-minded; accommodated; uneducated; lazy \\
\hline $\begin{array}{l}\text { 3. Religion and } \\
\text { traditionalism }\end{array}$ & 0 & Religious; Muslim or Christian; traditional; conservative; nationalist \\
\hline 4. Sociocultural elements & 0 & $\begin{array}{l}\text { European; oriental; EU; (not) modern; rich culture; historical; mix of cultures; } \\
\text { undeveloped; in crisis; external debt; poor; football; good cooks; like the Spanish; } \\
\text { brave; strong; speak fast }\end{array}$ \\
\hline \multirow{2}{*}{$\begin{array}{l}\text { 5. Sense of proximity or } \\
\text { distancing }\end{array}$} & + & Similar; interesting; attractive; handsome; lovely country \\
\hline & - & $\begin{array}{l}\text { Unknown; a secret; mysterious; distant; strange, different; exotic; confusing, } \\
\text { complicated; complex; Moors; Arabs; dangerous; radical; barbarian }\end{array}$ \\
\hline
\end{tabular}

(based on ignorance regarding the counterpart's people) felt by the respondents, and/or the desire not to expose themselves too much in what concerns their (or their people's) representations of the Other (lest they should reveal biases, or, again, ignorance). Subsequent focus group interviews with the students enabled us to confirm these assumptions.

There are some similarities in both groups' patterns of responses and also very strong dissimilarities related to the images that the participants presented regarding both their own people and their counterpart's. One important similarity concerns the tendency in both groups to present, in all associograms (with the exception of the indirect heteroimages in the Portuguese group), an image of the Portuguese and of the Turks as highly agreeable, extrovert peoples, two attitudinal and interpersonal positive traits that are liable to facilitate interaction, communication, and the establishment of relationships.

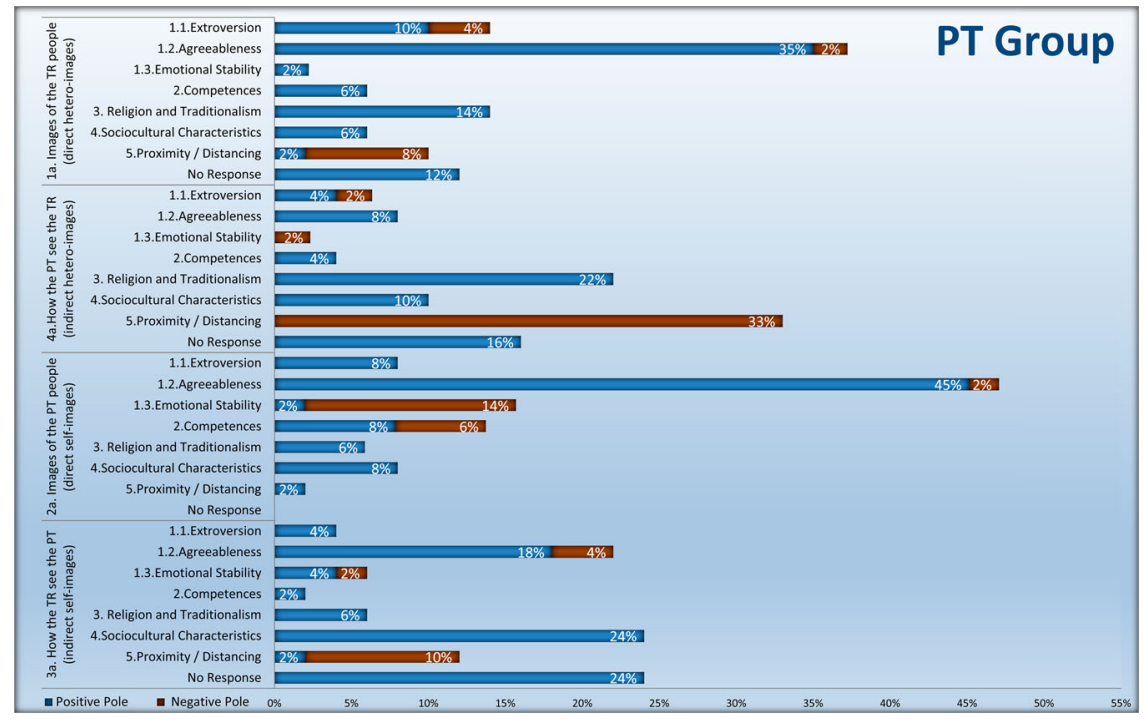

Figure 4. Categorization and indexing of the Portuguese Group's responses. 


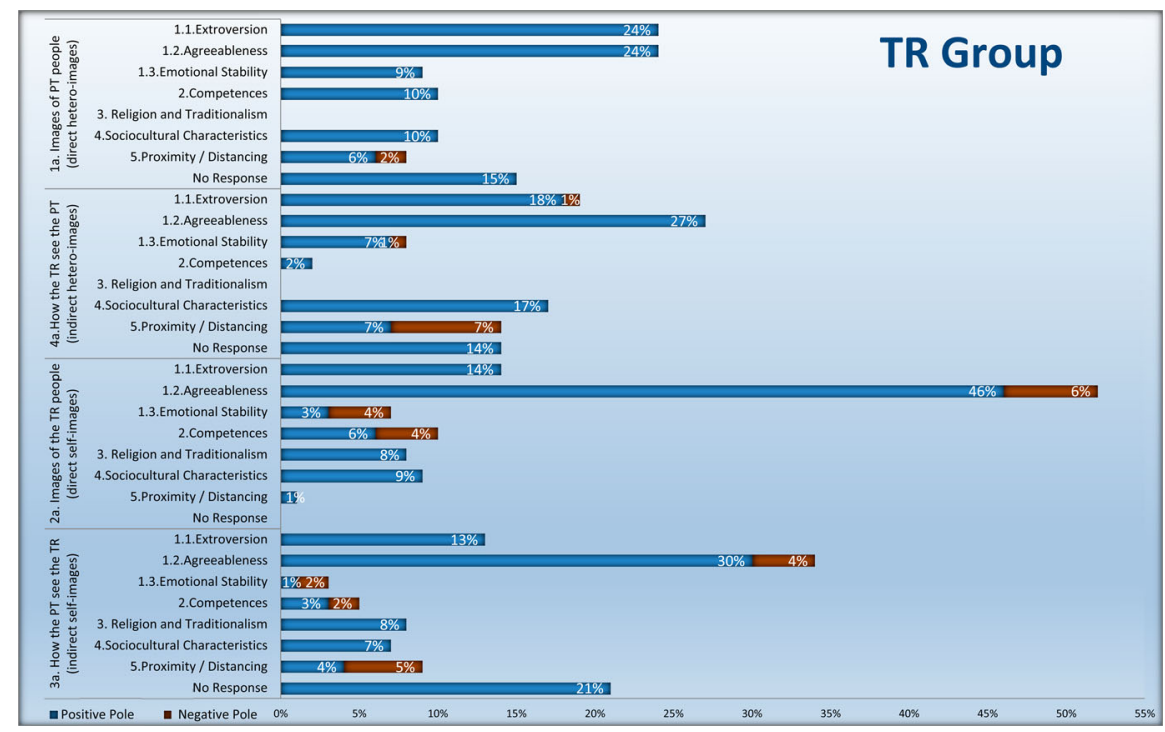

Figure 5. Categorization and indexing of the Turkish Group's responses.

As for the dissimilarities, perhaps the most striking one concerns the great disparity between the results of the direct (1a) and indirect hetero-image associograms (4a) in the case of the Portuguese group.

These results point out to the fact that the Portuguese group shares a clear perception that the Portuguese people in general construct an image of the Turkish people eminently based on a sense of difference and distancing. These results are quite relevant as the respondents themselves, dealing with such notions in their daily life, might be led to also assume a more negative perspective on the Turks. In fact, although in a much lesser degree, in their direct hetero-images (how they see the Turks), the Portuguese respondents reveal a clear sense of distancing even while they are learning their language and (to a greater or lesser degree) their culture.

Inversely, the Turkish group shows almost no disparity between the results referring to the direct hetero-images and the indirect hetero-images; in both cases, a more or less positive image of the Portuguese people is presented, and, at the same time, there is hardly any difference between what the respondents think about the Portuguese and their perception of what the Turkish people in general think.

Another divergence in the response patterns of the Portuguese and the Turkish is related to the 'Religion and Traditionalism' category. The Portuguese group reveals a strong tendency to include elements related to religion and traditionalism in their image of themselves and their counterpart, more so in the latter case. In fact, this dimension takes an extremely important role in the characterization of the Turks (in both direct and indirect hetero-images). In contrast, there is no reference in the Turkish group related to religion or traditionalism in their characterization of the Portuguese people (in both their direct and indirect hetero-images). Hence, in the context of intercultural understanding between the Portuguese and Turkish people, there is a strong imbalance regarding the importance of the religious and traditionalistic factor in the characterization of the Other, 
as it is extremely important for the Portuguese group and, apparently, not important at all for the Turkish group.

Another major factor of distinction found in the answers of both groups relates to the 'Sense of Proximity or Distancing' category. In the Portuguese group, the respondents give a strong relevance, in terms of both direct hetero-images and indirect self- and heteroimages, to elements connected to a sense of distancing between the two peoples, showing that this is a particularly important feature in their general construct of the image of the Turkish people. This sense of distancing, as we have seen, is particularly evident in the perception of how the Portuguese people see the Turkish, as the extremely high level of occurrences (33\%) accounts for.

These results deeply contrast with those found for the Turkish group, where the number of occurrences of items related to this category is substantially lower, and corresponds either to a clear sense of proximity (direct hetero-images), or to an equally valued sense of both proximity and distancing (indirect self- and hetero-images).

\section{Images of Portugal, Turkey, and the EU}

In the 'Images Questionnaire', we included a multiple-choice question asking the participants to associate a number of different topics/values to the EU, to their own country, and to their counterpart's (the topics could be connected to one, two, all or none of the options). Our aim was to assess, simultaneously, the main values the participants related to their own and their counterpart's countries, as well as to the EU.

Table 6 displays these topics arranged in the categories in which we grouped them in order to analyse the collected data.

Table 7 displays the results of this multiple-choice exercise showing the degree in which the participants associate each of the value categories to the EU and to their own country and their counterpart's.

The results presented in Table 7 show that both groups share a quite positive image of the EU, namely by revealing a high tendency to relate it to positive human values, freedom of religion and economic development, and a low tendency to relate it to religious influence at the political level. However, both groups show a low tendency to associate the EU with micro-communitarian values.

In terms of how the participants see their counterpart's country, we are confronted with quite different results between the two groups. While the Turkish group clearly demonstrates a low tendency to associate any of the given topics to Portugal, clearly revealing the lack of a well-structured image about the political and social panorama in Portugal,

Table 6. Topics presented to the participants and respective categories.

\begin{tabular}{ll}
\hline Categories/values & \multicolumn{1}{c}{ Presented topics } \\
\hline $\begin{array}{l}\text { Human values } \\
\text { Respect for difference }\end{array}$ & $\begin{array}{l}\text { Peace/Freedom of speech/Genre equality/Defence of human rights } \\
\text { Community values } \\
\text { Micro level }\end{array}$ \\
$\begin{array}{l}\text { Macro level } \\
\text { Religion }\end{array}$ & $\begin{array}{l}\text { Respect for the elderly/Social solidarity at the local level/Family values } \\
\text { Influence }\end{array}$ \\
$\begin{array}{l}\text { Freedom } \\
\text { Economic development }\end{array}$ & Society influenced by religious traditions and beliefs/Influence of religion in politics \\
\hline
\end{tabular}


Table 7. Values associated to the EU, Portugal, and Turkey.

\begin{tabular}{|c|c|c|c|c|c|c|c|}
\hline \multirow{2}{*}{\multicolumn{2}{|c|}{ Topics associated to.... }} & \multicolumn{2}{|c|}{ European Union } & \multicolumn{2}{|c|}{ Counterpart's country } & \multicolumn{2}{|c|}{ Own country } \\
\hline & & PT group & TR group & PT group & TR group & PT group & TR group \\
\hline \multicolumn{2}{|c|}{ Human values } & $\begin{array}{c}\text { High } \\
74 \%\end{array}$ & $\begin{array}{c}\text { High } \\
62 \%\end{array}$ & $\begin{array}{c}\text { Very low } \\
7 \%\end{array}$ & $\begin{array}{l}\text { Low } \\
39 \%\end{array}$ & $\begin{array}{c}\text { Average } \\
55 \%\end{array}$ & $\begin{array}{l}\text { Low } \\
39 \%\end{array}$ \\
\hline \multicolumn{2}{|c|}{ Valorization of difference } & $\begin{array}{l}\text { High } \\
65 \%\end{array}$ & $\begin{array}{c}\text { Average } \\
55 \%\end{array}$ & $\begin{array}{l}\text { Low } \\
22 \%\end{array}$ & $\begin{array}{l}\text { Low } \\
37 \%\end{array}$ & $\begin{array}{c}\text { Average } \\
44 \%\end{array}$ & $\begin{array}{c}\text { Average } \\
55 \%\end{array}$ \\
\hline \multirow{2}{*}{$\begin{array}{c}\text { Communitarian } \\
\text { values }\end{array}$} & Micro & $\begin{array}{l}\text { Low } \\
26 \%\end{array}$ & $\begin{array}{l}\text { Low } \\
25 \%\end{array}$ & $\begin{array}{c}\text { Very high } \\
82 \%\end{array}$ & $\begin{array}{l}\text { Low } \\
37 \%\end{array}$ & $\begin{array}{l}\text { Low } \\
37 \%\end{array}$ & $\begin{array}{c}\text { Very high } \\
81 \%\end{array}$ \\
\hline & Macro & $\begin{array}{l}\text { High } \\
77 \%\end{array}$ & $\begin{array}{c}\text { Average } \\
54 \%\end{array}$ & $\begin{array}{c}\text { Very low } \\
6 \%\end{array}$ & $\begin{array}{l}\text { Low } \\
39 \%\end{array}$ & $\begin{array}{l}\text { Low } \\
35 \%\end{array}$ & $\begin{array}{l}\text { Low } \\
32 \%\end{array}$ \\
\hline \multirow{2}{*}{ Religion } & Influence & $\begin{array}{l}\text { Low } \\
21 \%\end{array}$ & $\begin{array}{l}\text { Low } \\
32 \%\end{array}$ & $\begin{array}{c}\text { Very high } \\
91 \%\end{array}$ & $\begin{array}{l}\text { Low } \\
32 \%\end{array}$ & $\begin{array}{l}\text { Low } \\
38 \%\end{array}$ & $\begin{array}{l}\text { High } \\
78 \%\end{array}$ \\
\hline & Freedom & $\begin{array}{l}\text { High } \\
77 \%\end{array}$ & $\begin{array}{l}\text { High } \\
66 \%\end{array}$ & $\begin{array}{l}\text { Low } \\
24 \%\end{array}$ & $\begin{array}{l}\text { Low } \\
37 \%\end{array}$ & $\begin{array}{l}\text { High } \\
71 \%\end{array}$ & $\begin{array}{c}\text { Average } \\
46 \%\end{array}$ \\
\hline \multicolumn{2}{|c|}{ Economic Development } & $\begin{array}{c}\text { Very high } \\
82 \%\end{array}$ & $\begin{array}{l}\text { High } \\
77 \%\end{array}$ & $\begin{array}{c}\text { Average } \\
41 \%\end{array}$ & $\begin{array}{l}\text { Low } \\
31 \%\end{array}$ & $\begin{array}{l}\text { Low } \\
22 \%\end{array}$ & $\begin{array}{c}\text { Low } \\
(32 \%)\end{array}$ \\
\hline \multicolumn{8}{|c|}{ Scale: Very low - 1 - 20\% / Low - 21 - $40 \%$ / Average- 41 - $60 \%$ / High - $61-80 \%$ / Very high - $81-100 \%$} \\
\hline
\end{tabular}

the Portuguese group shows a much clearer and stabilized representation of their counterpart's country, revealing a quite negative image of Turkey. Indeed, we can perceive a very low association of this country with topics related to human and macro communitarian values, and to the valorization of difference and religious freedom, and a very high association with religious influence on politics.

It is interesting to note that both groups construct an image of their own country which is quite distinct from the one they construct regarding the EU, which seems to be seen as a world apart. This result seems even more meaningful in the Portuguese case, as Portugal has been an EU member since 1986.

\section{Discussion of the results}

According to Abdallah-Pretceille (1999), in interactions with the Other, the Other becomes 'the mirror of the self. As we have seen, intercultural communication is based on this 'mirroring process', which implies challenging the representations of not only the Other and the Other's culture, but also of one's own. In this sense, as a process involving this kind of mirror game of the reciprocal images of the interlocutors, intercultural interaction always departs from the speaker's pre-existent knowledge of him/herself and the Other, as well as from his/her attitudes towards the Other and towards interaction itself (cf. Byram, 1997, 2009; Raz1, 2012). This process, consequently, plays a fundamental role not only in communication, but also in the will to establish intercultural contacts and relate with the Other.

Our empirical study has revealed a clear asymmetry in this mirror game between the images that the Portuguese and the Turkish groups construct of their own and their counterpart's people, country, and culture. The Portuguese group shows a tendency to present an image of the Turkish people as quite different from their own, and a somewhat consolidated negative image of Turkey. At the same time, they clearly perceive that their 
own people in general have a strongly prejudiced image of the Turkish people, focusing on differences and distance and the reinforcement of identity borders, mainly concerning the religious factor, namely the fact that Turkey is a Muslim country. Inversely, the Turkish group reveals a high tendency to present an idea of similarity between the Portuguese and the Turks, focusing on similarities and on the effacement of identity borders. The Turkish group seems to consider that their people in general share a positive image of the Portuguese. At the same time, they show a 'mellow' image of Portugal, with no signs of prejudice, but revealing the lack of a consolidated image of this country.

In this sense, we can say that the Turkish group reveals a response pattern pointing to a relation of some enantiomorphism (mirror imaging) between the images of the Portuguese and Turkish peoples. Inversely, in the Portuguese group, we find a tendency to construct self- and hetero-images based on distinctive characteristics and traits. The relation between the self- and hetero-images presented is, thus, of a certain imagological distortion, that is, there is a tendency for differentiation and distancing between the images of the Portuguese people and of the Turkish people.

Thus, by presenting a strong similarity between self- and hetero-images, the Turkish group seems to meet the attitudinal preconditions required for the development of an effective intercultural understanding between people of both countries, and, consequently, Intercultural Dialogue. Inversely, the Portuguese group shows a greater tendency towards differentiation and distancing in relation to their counterpart, which may constitute a hindrance to intercultural communication and dialogue.

Both the Portuguese and the Turkish group reveal a great lack of awareness regarding each other, which unveils the necessity of developing FLE strategies aiming at fostering a deeper reciprocal awareness of the country, culture, and people whose language is being learnt. Unfortunately, students learning each other's language might feel reluctant to interact across cultures. Their lack of awareness regarding the Other might lead to stereotyping the Other, which can give origin to feelings of anxiety, stress, or even suspicion regarding intercultural interaction. Our data confirm that there is a strong need for both pedagogical contexts to go deeper into the development of the students' IC, mainly as related to 'critical cultural awareness' as a basis for relating self- and hetero-images. The efforts at the national political level to create a better relationship between Portugal and Turkey (as referred to in the introduction of this study) require awareness of this challenge and pedagogical development to deal with it.

\section{Conclusions and implications}

Whenever there is a lack of a perceived sense of shared identities, the contact with the Other involves a moment of potential stress and crisis, as the Other becomes a representation of the not known, unknown, or even a threat (cf. Camilleri, 1990).

In this context, our study recognizes the potential risk that, in interactions between the Portuguese and the Turks, the former might regard the latter as a threat, which may result in the development of strategies of avoidance to contact and interaction, whereas the Turks might regard the Portuguese as the unknown, or simply not known, which might lead them to attitudes of indifference towards their counterpart. There is therefore a need for the Portuguese group to develop positive images of the Turks and a sense of shared identities, and for the Turkish group to get a better knowledge of the Portuguese. 
In fact, although they clearly present a very positive image of the Portuguese and a sense of shared identities, they simply do not know enough about them. It is worth quoting one of Oscar Wilde's characters in this respect: 'There is only one thing in the world worse than being talked about, and that is not being talked about'.

In this sense, and in order to promote an effective rapprochement between the two countries and their peoples, there is a need to develop intercultural education strategies - to be applied in both countries - that should deepen reciprocal awareness, form positive mutual images, and deconstruct negative stereotypes or prejudiced representations. As we stressed at the beginning, FLE takes a fundamental role in such rapprochement, more specifically when assuming a critical intercultural stance.

In our perspective, a critical approach to Portuguese and Turkish FLE, together with its recognition as 'cultural politics' (Guilherme, 2002), must be implemented. This can be done by developing all the five dimensions that Guilherme attributes to FLE: (i) interactional; (ii) cultural; (iii) educational, where both teachers and students are seen as 'cultural workers' and 'transformative intellectuals'; (iv) political, in the sense that cultural realities should be not only interpreted, but also transformed for the better; (v) ethical, based on the struggle against discrimination and xenophobia, and the promotion of solidarity and cooperation between different peoples, countries, and cultures. Only thus can we effectively develop intercultural speakers and mediators who can actively contribute to the rapprochement between Portugal and Turkey and to the establishment of Intercultural Dialogue between the two countries.

Byram's model of IC gives important clues for the development of this critical intercultural approach to FLE, facilitating the adoption of a simultaneous etic (or culture-general) and emic (culture-specific) approach to culture, which opens the possibility of going beyond cultural 'folklorization' or 'erudition' towards a holistic and anthropological perspective of culture (cf. Marková, 2012). Byram's IC five component model should therefore be used as the basis for positive image deconstruction and reconstruction, enabling students to realize that social and cultural borders are in fact of an eminently symbolic nature, and what separates the different groups, in most cases, is exactly the will to construct a differentiation between them. Students can thus be led to understand how their social identities influence the way they see themselves and the Other, and, by adopting a view of otherness based on similarities, surpass a vision of otherness based merely on the identification of differences.

The pro-social attributes conferred by the two groups to both the Portuguese and the Turks (e.g. agreeableness and extraversion) may constitute the perfect basis for the further development of positive intercultural attitudes and for the raising of a stronger willingness to effectively cross the intercultural bridges between them. In the case of Turkish group, the development of a sense of shared identities regarding the Other can be developed on the basis of the similarity between the images the students present regarding their self- and hetero-images. In the case of the Portuguese group, the development of a sense of shared identities has to be based on the questioning of the factors that might be involved in the clear differentiation that the participants establish between the images of the Portuguese and of the Turks. One of these factors, for instance, refers to the weight given by the students to religion and traditionalism when it comes to the characterization of the Turks, which cannot be isolated from their perspectives regarding Islam itself. There is, effectively, a clear necessity to problematize and debate the students' 
perspectives on Islam, both at a general level and at the level of its real impact on Turkish society and culture.

For both groups, the question of Turkish EU membership can be used to discuss cultural, political, economic, social, and religious issues regarding such dichotomies as West vs. East, or Christianity vs. Islam. The current political discourse (see the 'Introduction' section) also presents important themes - such as the development of a 'Mediterranean solidarity', or the status of Portugal and Turkey as 'gateway' countries within the referred to 'triangular cooperation' - liable to be discussed in class in order to raise 'critical cultural awareness'.

Our study also revealed the need to develop efforts to 'decondition' (Dervin, 2006) the students regarding the way they interiorized conventional learning contents of FLE and the 'proper' way they should be taught. This 'deconditioning' seems to be even more important in the Turkish case, as the Turkish students tend to have a more formal conception of language education. In fact, Alptekin and Tatar (2011) recognize that, in the Turkish educational context, 'novel approaches to language teaching remain suspect in the eyes of many, irrespective of their contribution to learning' (p. 332). In this respect, Alptekin (2002) advocates that the 'communicative approach' to language teaching based on the 'model of the native speaker' should be abandoned in favour of an 'intercultural communicative approach', which we view as strongly connected with Byram's model of the intercultural speaker.

Finally, our study allows us to recommend some practical strategies to be developed in the FLE context that should enable students to become effective intercultural speakers. First, auto- and hetero-images - as depicted, for instance, in the present study - should be used as tools for the development of 'critical cultural awareness' in the context of FLE, by rousing the students' critical reflection and discussion. Secondly, critical reflection on cultural, social, economic, and political issues regarding both countries should be based on 'real materials', so as to avoid the cultural 'folklorization' or 'erudition', and, thus, the perpetuation of well-established preconceptions and stereotypes. Thirdly, online platforms should be created in which students from both countries can interact directly and exchange information and points of view. Finally, Portuguese and Turkish FLE students' mobility should be facilitated, as we are aware of how difficult it is for Turkish students to freely visit Portugal (or other EU countries) as Turkey is not part of EU. This is of course a political issue that should be addressed not only at the European level, but also within the bilateral relations between Portugal and Turkey.

We firmly believe that the fulfilment of these recommendations can effectually contribute to strengthen the 'special relation' between Portugal and Turkey as stated in the political discourses of both countries, and enable both Portuguese and Turkish students to effectively construct bridges and cross-over the gaps that still seem to separate them, whether geographical and institutional (e.g. geographical distance, EU membership), or symbolical (e.g. East and West, Muslim and Christian dichotomies).

\section{Notes}

1. Davutoğlu (2010), the current Turkish prime minister, and Minister of Foreign Affairs at the time, declared, for instance, that 
[the relations between the two countries] have been strengthening in a steady manner, fuelled by mutual respect and sympathy between our peoples [ ... ] our two countries have much in common $[\ldots]$ friendliness, generosity and sincerity $[\ldots]$ describe both our peoples $[\ldots]$ we share universal values such as democracy, pluralism and freedom that identify Europe.

In his turn, Cavaco Silva, the current Portuguese President, reaffirmed the Portuguese support for Turkey's accession to the EU in these terms:

With Turkey's accession to the EU, besides the enrichment brought by the integration of a great nation with a multifaceted cultural reality - the EU gains a growing strategic relevance, which will allow it to act with much greater weight in areas which are fundamental for its collective future. (Miranda, 2013)

2. For more information about the number of university institutions and students, both in Turkey and Portugal, please refer to Altınsoy (2011) and Direção-Geral de Estatísticas da Educação e Ciência (2013), respectively.

\section{Disclosure statement}

No potential conflict of interest was reported by the authors.

\section{Funding}

This paper is integrated in a broader $\mathrm{PhD}$ project supported by the Foundation for Science and Technology (FCT) and co-financed by the European Social Fund (ESF) under Grant SFRH/BD/ $48465 / 2008$.

\section{Notes on contributors}

Daniel Basílio has a graduation degree in Anglo-Portuguese Studies, a post-graduation in Educational Training by the Faculty of Social Sciences and Humanities of the New University of Lisbon, having concluded the Doctoral Programme in Didactics and Training, in the Department of Education of the University of Aveiro. The Foundation of Science and Technology (Portugal) has granted him a scholarship for his research project entitled 'Reciprocal images of Turkish and Portuguese university students: for an (inter)cultural mediation between Portugal and Turkey'. He is also a member of the Research Centre for Didactics and Technology in Teacher Education (CIDTFF).

Maria Helena Araújo e Sá is a Professor at the Department of Education of the University of Aveiro (Portugal), where she teaches Language Teacher Education, vice-coordinates the Research Centre for Didactics and Technology in Teacher Education (CIDTFF), and co-coordinates the LALE (Laboratory of Research and Training in Foreign Languages). She has coordinated and participated in several national and international projects concerning intercomprehension and plurilingual and intercultural communication and she has run several training courses at national and international levels, having, for instance, coordinated the Galapro - Education of trainers for intercomprehension in Romance languages - project financed by the EU.

Ana Raquel Simões has a graduation degree in Portuguese/English Studies and a PhD on Language Didactics by the University of Aveiro (UA). After developing a Post-Doctoral fellow (November 2006-March 2008), she became an Auxiliary Researcher in CIDTFF (Research Centre for Didactics and Technology in Teacher Education), and is now a Professor in the Department of Education of the same university. She has taken part in several scientific commissions, organization of scientific events and international and national research projects. She supervises several $\mathrm{PhD}$ and Masters' students and has developed research in the following areas: Intercultural Education, Plurilingualism, Teacher Education, and Student Mobility. 


\section{References}

Abdallah-Pretceille, M. (1999). L'éducation interculturelle. Paris: PUF.

Abric, J. C. (1994). Les représentations sociales: Aspects théoriques. In J. C. Abric (Dir.), Pratiques sociales et représentations (pp. 11-36). Paris: PUF.

Alptekin, C. (2002). Toward intercultural communicative competence in ELT. ELT Journal, 56, 5764.

Alptekin, C., \& Tatar, S. (2011). Research on foreign language teaching and learning in Turkey (2005-2009). Language Teaching, 44, 328-353.

Altınsoy, S. (2011). A review of university facilities in Turkey. CELE Exchange, Centre for Effective Learning Environments, No. 2011/06. Paris: OECD Publishing. Retrieved from http://dx.doi.org/ $10.1787 / 5 \mathrm{~kg} 5 \mathrm{c} 8 \mathrm{cch} 88 \mathrm{p}-\mathrm{en}$

Araújo e Sá, M. H., De Carlo, M., \& Melo-Pfeifer, S. (2010). O que diriam sobre os portugueses? [What would they say about Portuguese people?]: Intercultural curiosity in multilingual chatrooms. Language and Intercultural Communication, 10, 277-298.

Araújo e Sá, M. H., \& Pinto, S. (2006). Imagens dos outros e suas línguas em comunidades escolares: Produtividade de uma temática de investigação em educação linguística. In R. Bizarro (Org.), A escola e a diversidade cultural. Multiculturalismo, interculturalismo e educação (pp. 227-240). Porto: Areal Editores.

Barth, F. (1995). Les groupes éthiques et leurs frontières. In P. Poutignat, J. Streiff-Fenart, F. Barth \& J. Bardolph (Eds.), Théories de l'ethnicité (pp. 203-249). Paris: PUF.

Bayyurt, Y. (2006). Non-native English language teachers' perspective on culture in English as a Foreign language classrooms. Teacher Development, 10, 233-247.

Byram, M. (1997). Teaching and assessing intercultural communicative competence. Clevedon: Multilingual Matters.

Byram, M. (2007, January 26-27). Plurilingualism in Europe and its implications. Paper presented at Preparing for the world of work - language education for the future. Berlin, Germany: British Council.

Byram, M. (2008). From foreign language education to education for intercultural citizenship: Essays and reflections. Clevedon: Multilingual Matters.

Byram, M. (2009). Intercultural competence in foreign language education. In D. K. Deardorff (Ed.), The SAGE handbook of intercultural competence (pp. 321-332). Thousand Oaks, CA: Sage.

Camilleri, C. (1990). Identité et gestion de la disparité culturelle: Essai d'une typologie. In C. Camilleri, J. Kastersztein, E. M. Lipiansky, \& H. Malewska-Peyre (Eds.), Stratégies identitaires (pp. 85-110). Paris: PUF.

Castellotti, V., \& Moore, D. (2002). Représentations sociales des langues et enseignements. Strasbourg: Conseil de l'Europe.

Coste, D. (2001). De plus d'une langue à d'autres encore penser les compétences plurilingues? In V. Castellotti (Dir.), D’une langue à d'autres: pratiques et représentations (pp. 191-202). Rouen: Publications de l'Université de Rouen.

Council of Europe. (2001). Common European framework of reference for languages: Learning, teaching and assessment. Cambridge: Cambridge University Press.

Council of Europe. (2008). White paper on intercultural dialogue: Living together as equals in dignity. Strasbourg: Council of Europe.

Cuche, D. (1999). A noção de cultura nas ciências sociais. Bauru: EDUSC.

Davutoğlu, A. (2010, July 14). Turquia, Portugal e a Europa. Público. Retrieved from http://www. publico.pt/opiniao/jornal/turquia-portugal-e-a-europa-19765413

Deardorff, D. K. (Ed.) (2009). The SAGE handbook of intercultural competence. Thousand Oaks, CA: Sage.

De Pietro, J., \& Müller, N. (1997). La construction de l'image de l'autre dans l'interaction. Des coulisses de l'implicite à la mise en scène. Bulletin Suisse de Linguistique Appliquée, 65, 25-46.

Dervin, F. (2006). Reflections on the deconditioning of language specialists in Finnish higher education. In F. Dervin \& E. Suomela-Salmi (Eds.), Intercultural communication and education: Finnish perspectives (pp. 105-123). Bern: Peter Lang. 
Direção-Geral de Estatísticas da Educação e Ciência. (2013). Estatísticas da Educação 2011/2012. Retrieved from http://www.dgeec.mec.pt/np4/218/\%7B \$clientServletPath\%7D/?newsId= 308\&fileName=EEF2012.pdf

Dörnyei, Z. (2003). Attitudes, orientations, and motivations in language learning: Advances in theory, research, and applications. Oxford: Blackwell.

European Commission. (2013). A Statistical Overview of the ERASMUS Programme in 2011-12 Annex 9: Inbound and outbound study exchanges in 2011-12. Retrieved from http://ec.europa. eu/education/library/statistics/ay-11-12/annex-09-in-out-study-exchange-87_en.pdf

Fantini, A. E., \& Tirmizi, A. (2006). Exploring and assessing intercultural competence. Brattleboro, VT: Federation EIL.

Genç, B., \& Bada, E. (2005). Culture in language learning and teaching. The Reading Matrix, 5, 7384.

Guilherme, M. (2002). Critical citizens for an intercultural world: Foreign language education as cultural politics. Clevedon: Multilingual Matters.

Jodelet, D. (1997). Les représentations sociales. Paris: PUF.

Lusa (2014, September 12). Rui Machete reitera apoio na adesão da Turquia à UE. Diário de Notícias. Retrieved from http://www.dn.pt/politica/interior.aspx?content_id=4121616\&page=-1

Lustig, M. W., \& Koester, J. (2010). Intercultural competence: Interpersonal communication across cultures. Boston, MA: Allyn and Bacon.

Mannoni, P. (1998). Les représentations sociales. Paris: PUF.

Mariko, H. (2005). La notion de représentation en didactique des langues. Enseignement du français au Japon, 33, 69-86.

Marková, I. (2012). Social representations as anthropology of culture. In J. Valsiner (Ed.), The Oxford handbook of culture and psychology (pp. 487-509). Oxford: Oxford University Press.

Masgoret, A. M., \& Gardner, R. C. (2003). Attitudes, motivation, and second language learning: A meta-analysis of studies conducted by Gardner and associates. Language Learning: A Journal of Research in Language Studies (United States), 53, 167-210.

McCrae, R. R., \& Costa, P. T. (1997). Personality trait structure as a human universal. American Psychologist, 52, 509-516.

McCrae, R. R., \& Costa, P. T. (2006). Perspectives de la théorie des cinq facteurs (TCF): Traits et culture. Psychologie Française, 51, 227-244.

Miranda, A. (2013, May 6). Cavaco renova votos para adesão da Turquia à EU. Público. Retrieved from http://www.publico.pt/politica/noticia/cavaco-renova-votos-para-adesao-da-turquia-a-ue1593554

Pardal, L., \& Correia, E. (1995). Métodos e técnicas de investigação social. Porto: Areal Editores.

Porcher, L. (1997). Lever de rideau. In G. Zarate \& M. Candelier (Org.), Les représentations en didactique des langues et cultures (pp. 11-28). Paris: Didier Erudition.

Razı, S. (2012). Developing the inventory of cultural components to assess perception in language learning. Novitas-ROYAL (Research on Youth and Language), 6, 169-186.

Rouault, S. (2001). Les langues vivantes dans le système éducatif français. Motivations du choix et représentations. Travaux de Didactique du FLE, 46, 63-73.

Sinicrope, C., Norris, J., \& Watanabe, Y. (2007). Understanding and assessing intercultural competence: A summary of theory, research, and practice. Second Language Studies, 26, 1-58.

Spitzberg, B., \& Chagnon, G. (2009). Conceptualizing intercultural competence. In D. K. Deardorff (Ed.), The SAGE handbook of intercultural competence (pp. 2-52). Thousand Oaks, CA: Sage publications.

Vasseur, M. T. (2001). Places discursives, imaginaire dialogique et apprentissage de la langue. In D. Moore (Coord.), Les représentations des langues et de leur apprentissage. Références, modèles, données et méthodes (pp. 133-148). Paris: Didier.

Walt, C. (2004). Language and identity: The limits of instrumental motivation. In A. Coetzee (Ed.), Proceedings of the 21st world congress of the world federation of modern languages associations identity and creativity in language education (pp. 693-698). Johannesburg: RAU University.

Wojciszke, B. (2005). Morality and competence in person- and self-perception. European Review of Social Psychology, 16, 155-188. 
Yin, R. (2009). Case study research: Design and methods. Thousand Oaks, CA: Sage.

Zarate, G., Gohard-Radenkovic, A., Lussier, D., \& Penz, H. (2004). Cultural mediation in language learning and teaching. Strasbourg: Council of Europe.

Zehir Topkaya, E., \& Demir, B. (2011). The effects of a course about culture and culture teaching: Do pre-service teachers' conceptions change? In S. Ağıldere \& N. Ceviz (Eds.), Proceedings of the 10th international language, literature and stylistics symposium (Vol. 2, pp. 592-601). Ankara: Gazi University. 